150 Years of Boom and Bust

What Drives Mineral Commodity

Prices?

Martin Stuermer

Federal Reserve Bank of Da llas

Research Department

Working Paper 1414 


\title{
150 Years of Boom and Bust: What Drives Mineral Commodity Prices?
}

\author{
Martin Stuermer*
}

December 12, 2014

\begin{abstract}
My paper provides long-run evidence on the dynamic effects of supply and demand shocks on mineral commodity prices. I assemble and analyze a new data set of price and production levels of copper, lead, tin, and zinc from 1840 to 2010. Price fluctuations are primarily driven by demand rather than supply shocks. Demand shocks affect the price persistently for up to fifteen years, whereas the effect of mineral supply shocks persists for a maximum of five years. My paper shows that price surges caused by rapid industrialization are a recurrent phenomenon throughout history. Mineral commodity prices return to their declining or stable trends in the long run.
\end{abstract}

JEL classification: E30, Q31, Q33, N50

Keywords: Mineral Commodity Markets, Prices, Non-renewable resources, SVAR

*Federal Reserve Bank of Dallas, Research Department, 2200 N. Pearl St, Dallas, TX 75201. Email: martin.stuermer@dal.frb.org. For helpful comments, I thank Juergen von Hagen, Robert Pindyck, Lutz Kilian, Joerg Breitung, Martin Hellwig, Dirk Krueger, Christiane Baumeister, Gordon Rausser, Aaron Smith, Scott Irvin, Martin Helbling, Dirk Foremny, Benjamin Born, Felix Wellschmied, Peter Wolff, Mike Weiss, and participants in presentations given at UC Berkeley, UC Davis, U Illinois at Urbana-C., Michigan SU, IMF, ECB, U Bonn, U Cologne, FRB Dallas, Federal Reserve Board, DIW Berlin, UC Louvain, the AEA meeting in Philadelphia, the EEA meeting in Gothenburg, and the EHA meeting in Boston. All remaining errors are mine. I am grateful for grants from the German Development Institute. The views in this paper are those of the author and do not necessarily reflect the views of the Federal Reserve Bank of Dallas or the Federal Reserve System. An online-appendix is available at https://sites.google.com/site/mstuermer1/research-1. 


\section{Introduction}

The prices of mineral commodities, including fuels and metals, have repeatedly undergone periods of boom and bust over the last 150 years Cuddington and Jerrett, 2008; Jacks et al., 2011). These long-term fluctuations affect the macroeconomic conditions of developing and industrialized countries (World Trade Organization, 2010; IMF, 2012). Strong booms have repeatedly raised the issue of "security of supply" to the top of governmental agendas, while bust periods have stirred fears about declining terms of trade and government income.

However, the theoretical literature is far from conclusive on the driving forces behind these long-term fluctuations $\square^{\square}$ Extensions of the Hotelling 1931 model explain price fluctuations by referring to irregular exploration for deposits and hence, focusing on the supply side (Fourgeaud et al., 1982; Cairns and Lasserre, 1986). Competitive storage models ultimately leave the source of shocks open (Wright and Williams, 1982). Another strand of literature on the subject stresses the role of storage in the presence of expected supply shortfalls in explaining price fluctuations (Alquist and Kilian, 2010). Finally, Frankel and Hardouvelis (1985), Barsky and Kilian (2002), and other authors point to monetary policy as a major driving force.

Empirical work tends to focus on the oil market. Hamilton (2008) claims that supply shocks account for the broad behavior of the price of crude oil. In contrast, Kilian (2008b,

\footnotetext{
${ }^{1}$ See Carter et al. (2011) for a detailed summary of theories on fluctuations in commodity markets.
} 
2009) and Kilian and Murphy (2013) show that fluctuations in the price of oil are driven mainly by demand shocks due to the global business cycle. Pindyck and Rotemberg (1990) stress that macroeconomic variables, such as money supply, help to explain the concurrent movements of commodity prices. Frankel and Rose (2010) find that, while global output and inflation have some effect on the prices of agricultural and mineral commodities, they are outstripped by volatility and inventories. Empirical evidence on storage models is also contradictory. Deaton and Laroque (1996) conclude that demand shocks are the dominant source of price fluctuations, while Cafiero et al. (2011) show that supply shocks are the main drivers.

This paper studies the dynamic effects of demand and supply shocks on mineral commodity prices from 1840 to 2010. I quantify the relative contribution of these shocks to price fluctuations. My study covers a considerably longer time period than most previous work based on a new data-set, thus allowing me to include a long series of booms and busts.

I assemble annual data for prices and world mineral production for copper, lead, tin, and zinc, as well as world GDP. I chose mineral commodity markets that exhibit characteristics that make a long-run analysis feasible. Copper, lead, tin, and zinc were traded on the London market as fungible and homogeneous goods in an integrated world market over the long period considered here. They exhibit a substantial track record in industrial use. Hence, they have long-term characteristics that other mineral commodities such as iron ore, crude oil, or coal have only gained in recent times. 
I apply a structural vector auto-regressive (SVAR) model to each of the four markets. I use long-run restrictions to identify three different shocks to the real price of the commodity concerned: "commodity supply shocks," e.g., a disruption in the physical production of the respective commodity due to strikes or cartel action; "world output-driven demand shocks," which include shocks in global demand for all commodities due to, e.g., an unexpected strong growth of world GDP; and "other demand shocks." The latter include all shocks that have no correlation with "commodity supply shocks" and "world output-driven demand shocks". I interpret them as mainly capturing unexpected changes in inventories.

My identification scheme allows me to leave the short-run relationships unrestricted. The restrictions on the long-run effects assume that shocks to the supply of a specific commodity and "other demand shocks" do not have long-run effects on world GDP. This implies the assumption that productivity losses due to searching for substitutes for copper, lead, tin, or zinc by other materials are too small to be of relevance to world GDP in the long term. "Other demand shocks" do not affect commodity production in the long run, which is based on the notion that changes in inventory demand only increase capacity utilization, but do not lead to capacity expansions of existing mines. I check the plausibility of the identified shocks through narrative evidence from the economic history of the examined markets.

This paper's primary conclusion is that price fluctuations are primarily driven by demand shocks rather than by supply shocks over the last 150 years. Shocks to world demand due to e.g. periods of rapid industrialization or economic crisis have always driven the large 
booms and busts in prices. These demand shocks have large and statistically significant effects on prices that persist for five to five-teen years. Commodity supply shocks exhibit a pronounced impact on price for a maximum of five years only in tin and copper markets. These two market exhibit highly concentrated industry structures and government intervention. Furthermore, world commodity production is positively affected by demand shocks driven by world GDP. The estimated deterministic trends are rather stable or even decreasing.

My paper is to my knowledge the first to provide long-term evidence on demand and supply shocks in commodity markets. In contrast to Erten and Ocampo (2012) and Jacks (2013), who extract "super-cycles" from various commodity prices and indexes since the 19th century, I am able to control for the supply side and can identify the contribution and persistence of the different types of shocks in a structural VAR model. My result of a the strong contribution of demand shocks to price fluctuations over the long run is in line with the results on the oil market for the period after 1973 by Kilian (2009) and Kilian and Murphy (2013). In contrast to these studies, I use data over a far longer time horizon, which makes it possible to examine many more boom and bust periods. This allows me to examine the dynamic effects of these large shocks to price and to find a far longer persistence of the effects of shocks on prices. As I examine different commodity prices, I am also able to outline how different market structures affect the dynamic effects of the different shocks. Finally, all examined commodity prices were strongly upward driven by "world output-driven demand shocks" due to post-war reconstruction and the economic 
rise of Japan until the first half of the 1970s. This suggests that the oil price spike in 1973 might have partly been driven by the lifting of price controls in 1973, which caused the price to catch up to the high levels of other commodity prices attributable to the accumulated effect of demand shocks.

My results emphasize that extensions of the seminal Hotelling (1931) model, such as those by Arrow and Chang (1982), Fourgeaud et al. (1982), and Cairns and Lasserre (1986), which explain price fluctuations by supply shocks, are of less relevance in explaining the observed fluctuations. Instead, my support the importance of models that take into account demand shocks due to world GDP such as Dvir and Rogoff (2010), Mitraille and Thille (2009), Bodenstein et al. (2012). My work also points to demand rather than supply shocks as an interpretation of shocks in competitive storage models (Gustafson, 1958a, b; Wright and Williams, 1982).

My findings on the importance of "other demand shocks" point to inventories as a source of fluctuations rather than a calming agent. This is in contrast to the classical competitive storage models and rather provides long-term evidence in support of Alquist and Kilian (2010), Kilian and Lee (2013), Kilian and Murphy (2013), and others who maintain that storage in the presence of expected supply shortfalls helps to explain price fluctuations. Narrative evidence in this paper, however, suggests that shocks due to changes in inventories are primarily driven by producer cartels and government stockpiling, and only in recent times by the "precautionary" behavior of consumers or investors in the markets examined here. 
The empirical evidence on the different effects of commodity supply shocks on prices, which appears to increase with the importance of concentrated industry structures and government intervention in the markets, is in contrast to industrial organization models that predict higher product market concentration will reduce price volatility (see Slade and Thille, 2006).

My results also contribute to the literature on the long-run trends in commodities that is not conclusive so far (see Pindyck, 1999; Lee et al., 2006; Slade, 1982). I provide evidence for non-increasing mineral commodity prices, controlling for the effects of different shocks on prices. This is in line with evidence over shorter time periods provided by Krautkraemer (1998), Cynthia-Lin and Wagner (2007) and others.

The results are robust for different specifications, including different lag lengths, a more conventional identification scheme based on short-run restrictions (Kilian, 2009), and also in sub-periods. The results hold if I use a different data set, including New York instead of London prices, and employ different deflators.

My results have important implications for optimal fiscal and macroeconomic policy responses in commodity exporting countries, as it is important to know, first, how persistent a unexpected price change is, and second, to identify the driving force behind the price change (see Barsky and Kilian, 2002; Kilian, 2008). My results suggest that the effects of the large demand shocks attributable to China in 2003 to 2007 dissipate in their effect on prices. Unless there are no new positive demand shocks, the results suggest that current prices might further fall, as supply catches up and prices return to their long-run 
trend. Commodity exporters should thus prepare for a further down swing of mineral commodity prices, which exhibits strong effects on external and fiscal balances. The results also illustrate that self-imposed supply restrictions by a group of exporting countries are at most only temporarily effective in some markets but are ineffective in increasing prices over the long-run.

For countries that import mineral commodities, my results indicate that if the past is any guide to the future, apprehensions about the security of the supply are rather exaggerated for the broadly used mineral commodities examined here. Various forms of subsidies for overseas mining and the reduction of import dependencies as well as "resource diplomacy", are of questionable impact given that these mineral commodities are traded on world markets and prices react only moderately to supply restrictions in the short run.

I have organized the remainder of this paper as follows. In section 2, I describe the construction of my data set. Section 3 focuses on the econometric model and the scheme used to identify and distinguish the different structural shocks. In sections 4 and 5 , I present empirical results and robustness checks for copper, lead, tin, and zinc. Section 6 concludes.

\section{A New Data Set for Long-Run Analysis}

I choose to examine those mineral commodity markets, notably copper, lead, tin, and zinc, where a long-run analysis is feasible. These markets have long-term characteristics that other mineral commodities, such as steel and crude oil, have only gained in recent times. 
First, there is strong evidence that these four mineral commodities were traded in integrated world markets over the examined time period from 1840 to 2010 (see Klovland, 2005, O'Rourke and Williamson, 1994; Labys, 2008; Stuermer and von Hagen, 2012). This implies that price movements in the annual dataset are in accordance with the law of one price across different areas of the world. The levels of prices might differ due to transportation costs or trade barriers, even though these two factors were relatively unimportant in these markets when compared to, e.g., steel or coal markets. During the two World Wars commodity markets disintegrated due to price and supply controls (Backman and Fishman, 1941; Findlay and O'Rourke, 2007). I will account for this by using yearly dummies for the war periods and the three consecutive years.

Second, London has been and still is the principal marketplace to establish prices in these markets (Schmitz, 1979; Rudolf Wolff \& Co Lt., 1987, Slade, 1991). In comparison to U.S. price data, London prices reflect market prices over the entire time period rather than producer prices, as in some periods in the U.S.

Third, the four mineral commodities have been traded as rather homogeneous goods across time. For example, the purity of traded copper in 1900 was $99.97 \%$ while it is 99.99\% today. The other three mineral commodities possess this feature as well.

Fourth, these mineral commodities exhibit a substantial track record in industrial use and are still among the top twenty-five in value of world production. The four mineral commodities have been used for several thousand years. They are inputs either in pure form or as a alloys to a broad variety of intermediate and manufacturing goods. Their 
uses range from tools, home appliances, electronics and machinery to transportation and construction.

I have compiled annual data for real prices and world production of copper, lead, tin, and zinc, as well as world GDP over the time period from 1840 to 2010 2 With respect to world market prices, I make use of annual nominal price data for copper, lead, tin, and zinc from the London Metal Exchange (LME) and its predecessors. The prices are in British pounds $(£)$ for most of the period covered in this study. Starting in the middle of the 1970s, they have been given in U.S. dollars $(\$)$, and I have transformed them to British pounds by using annual exchange rates. For robustness checks, I have collected U.S.-American prices.

Following Krautkraemer (1998) and Svedberg and Tilton (2006), I deflate all nominal prices by the respective consumer price indices (CPI) for the U.K. and the U.S. I use producer price indices (PPI) as a robustness check. To obtain the U.S.-PPI, I have spliced together the wholesale price index for all commodities by Hanes (1998) and the producer price index for all commodities from the U.S. Bureau of Labor Statistics (2011). I have constructed the U.K.-PPI based on data from Mitchell (1988) and the World Bank (2012) in the same way.

\section{Insert Figure 1 about here.}

I have assembled data on the world production of the four mineral commodities from

\footnotetext{
${ }^{2}$ See the Online-Appendix for data sources and description.
} 
several sources. I use mine output or smelter output for earlier times and refined output where available for the 20th century. World production includes production from primary as well as recycled materials. However, the differentiation between primary and secondary materials is not easy, since so-called "new scrap" accrues across the different stages of the production process. "New" and "old" scrap are also fed back in the production process at different stages according to quality. Overall, I have tried to keep the data series as consistent as possible.

I use world GDP data from Maddison (2010) and The Conference Board (2012) as a measure of global economic activity that drives the demand for mineral commodities $!^{3}$ Maddison's data set only provides annual world GDP data from 1950 onwards. I sum up country based annual data for the time period before 1950. For those years where countrybased annual data is missing, I interpolate the data with linear trends. For European countries and Western offshoots, I compute their respective shares of output relative to neighboring countries, where data is available. I then interpolate these shares and multiply them with data from those countries, where annual data is available. This process assumes that the business cycle of these countries moves in tandem to that of their neighboring countries.

\footnotetext{
${ }^{3}$ This is in contrast to Kilian (2009) and Kilian and Murphy (2013) who create and employ a freight rate index. They argue that this is a better proxy for business cycle driven demand for oil as it does not include, e.g., effects of fluctuations of economic activity in the service sector. However, I decided to use world GDP because to my knowledge it is the only proxy for which data is available over the period considered.
} 


\section{Identifying Shocks to Mineral Commodity Prices}

I use a three-variable, structural VAR model with long-run restrictions to decompose unpredictable changes in real mineral commodity prices into three mutually uncorrelated shocks, notably "world output-driven demand shocks", shocks to the supply of the respective commodity, and "other demand shocks". ${ }^{4}$

The basic idea of the variance decomposition is to find what amount of information each variable, notably world GDP and world mineral production, contributes to the world mineral commodities price in the auto-regression. It hence shows how much of the predicted error variance of the mineral commodity price can be explained by exogenous shocks to world GDP and world mineral production.

The vector of endogenous variables is $z_{t}=\left(\Delta Y_{t}, \Delta Q_{t}, P_{t}\right)^{T}$, where $\Delta Y_{t}$ refers to the percentage change in world GDP, $\Delta Q_{t}$ denotes the percentage change in world primary production of the respective mineral commodity, and $P_{t}$ is the log of the respective real commodity price. The matrix of deterministic terms $D_{t}$ consists of a constant, a linear trend, and annual dummies during the two World War periods and the three years immediately after. The structural VAR representation is

\footnotetext{
${ }^{4}$ Blanchard and Quah $\sqrt{1989)}$ have introduced this methodology to explain fluctuations in GNP and unemployment. I use this methodology to explain fluctuations in mineral commodity prices. It is therefore important to keep in mind that Blanchard and Quah (1989) identify and interpret demand and supply shocks at the aggregate level, whereas I do so at the level of a specific commodity market.
} 


$$
A z_{t}=\Gamma_{1}^{*} z_{t-1}+\ldots+\Gamma_{p}^{*} z_{t-p}+\Pi^{*} D_{t}+B \epsilon_{t}
$$

The reduced form coefficients are $\Gamma_{j}=A^{-1} \Gamma_{j}^{*}$ for $(j=1, \ldots, p)$, and $\epsilon_{t}$ is a vector of serially and mutually uncorrelated structural innovations. The relation to the reduced form residuals is given by $u_{t}=A^{-1} B \epsilon_{t}$. I choose the number of lags $p$ according to the Akaike information criterion (AIC) for the benchmark regressions.

To compute the structurally identified impulse responses, I estimate the contemporaneous impact matrix $C=A^{-1} B$ by $\hat{C}=\hat{\Phi}^{-1} \hat{\Psi}=\hat{\Phi}^{-1} \operatorname{chol}\left[\hat{\Phi} \hat{\Sigma}_{u} \hat{\Phi}^{\prime}\right]$. The matrix of accumulated effects of the impulses is $\Phi=\sum_{s=0}^{\infty} \Phi_{s}=\left(I_{K}-\Gamma_{1}-\ldots-\Gamma_{p}\right)^{-1}$. I need $K(K-1) / 2=3$ restrictions on the long-run matrix of structural shocks $\Psi$ to identify the structural shocks of the VAR. I hence assume that $\Psi$ is lower triangular and obtain it from a Choleski decomposition of the matrix $\hat{\Phi} \hat{\Sigma}_{u} \hat{\Phi}^{\prime}$. (See Lütkepohl and Krätzig, 2004)

Assuming that $\Psi$ is lower triangular means that I place zero restrictions on the upperright hand corner of the long-run impact matrix. Thereby, I make the assumption that shocks to the supply of the respective mineral commodity and "other demand shocks" affect world GDP in the short-run, but not in the long-run. Furthermore, "other demand shocks" exhibit only a transitory effect on mineral commodity production. These assumptions lead to the identification of the following three shocks: 


\section{World Output-Driven Demand Shocks}

I construct the "world output-driven demand shocks" in such a way as to capture shocks to the global demand for all mineral commodities due to unexpectedly strong expansions or contractions of world GDP. They thus include unexpectedly strong periods of industrialization such as those of Great Britain, Germany, and the U.S. in the 19th century, Japan in the 20th century, and China and other emerging economies at the beginning of the 21st century.

The long-run restrictions mean that I refer to "world output-driven demand shocks" as those shocks to global real GDP that are neither explained by the short-run effects of shocks to the supply of the respective mineral commodity nor by the short-run effects of "other demand shocks".

I hence impose the restriction that shocks to the production of the mineral commodity which are not driven by "world output-driven demand shocks" only have a temporary effect on world GDP. This assumption seems strong, as one might argue that a reduction in inputs of a certain commodity might affect productivity and hence, world GDP in the

long term. However, Barsky and Kilian (2004) state that U.S. productivity losses due to the search for substitutes for oil are too small to be relevant. They sum up that none of the models which establish a link from oil price shocks to productivity changes "can claim solid empirical support." Kilian (2009) demonstrates that unanticipated oil supply shocks exhibit a statistically significant impact on the level of U.S. GDP only for the first two years and then become insignificant. Since the other mineral commodities examined here 
are of even less importance to world GDP than crude oil, I believe that my assumption is reasonable.

Moreover I assume that shocks to mineral commodity prices due to "other demand shocks" exhibit no long-term effect on world GDP. Certainly an increase in a commodity price decreases the income of consumers in the importing countries. At the same time, it increases the income of consumers in exporting countries so that there is no effect on world GDP from the aggregate demand side. Even in the case of crude oil, Rasmussen and Roitman (2011) show that oil price shocks on a global scale exhibit only small and transitory negative effects on a slight majority of countries.

\section{Commodity Supply Shocks}

"Commodity supply shocks" capture shocks to the production of the respective mineral commodity due to unexpected changes in production caused by, e.g., cartels, strikes, or natural catastrophes. I define them as those innovations to the production of the respective commodity that are driven neither by the short and long-term effects of "world outputdriven demand shocks", nor by the short-term effects of "other demand shocks". I hence assume that "commodity supply shocks" and "world output-driven demand shocks" affect the world's production of the respective commodity in the long run. In contrast, price changes driven by "other demand shocks" exhibit only a transitory effect on the world production of the respective mineral commodity. They hence affect only capacity utilization of the extractive sector, but not long-term investment decisions. This is plausible, given 
the fact that expanding extraction capacities exhibits high upfront costs and takes many years (Radetzki, 2008; Wellmer, 1992).

\section{Other Demand Shocks}

"Other demand shocks" encompass all innovations to the respective real mineral commodity price that are driven neither by "world output-driven demand shocks" nor "commodity supply shocks". "Other demand shocks" hence capture all shocks that are uncorrelated to these two latter shocks. I interprete these shocks as mainly capturing changes in the demand for inventories of mineral commodities which stem from three different sources: 1) government stocking programs, 2) producers with market power who increase their inventories in an attempt to increase prices, and 3) shifts in expectations of the downstream processing industry about the future supply and demand balance (see Kilian, 2009; Kilian and Murphy, 2013, on the last point). I do not directly include a proxy for inventories in this study because long-term data is missing.

"Other demand shocks" may also include unexpected changes in the intensity of use of the respective mineral commodity in the production of world GDP. The intensity of use reflects the quantity of a mineral commodity that an economy needs to produce one unit of output. It is driven by several factors: 1) technical improvements that either decrease or increase the quantity of a mineral commodity used to produce a specific good, 2) substitution by other materials, 3) changes in the structure of world output (e.g., a higher share of services), fourth, saturation of markets, and 4) government regulations that change the 
use of materials (for example, the phase-out of lead additives in gasoline see (Cleveland and Szostak, 2008)). However, all of these factors have partly offsetting effects and are rather gradual, long-term processes, especially on the global level (see e.g., Pindyck, 1980). Even government regulation, such as that imposed on lead additives, has become set in a continuous process of phasing-out over several decades on a world scale. These gradual processes are primarily captured in the long-run deterministic trend in the regression.

\section{Empirical Results}

I employ ordinary least squares to consistently estimate the reduced-form coefficients of the VAR models of each of the four mineral commodity markets. On the basis of these estimates, I obtain the contemporaneous and long-run matrices by the Cholesky decomposition as described above. I use a recursive-design wild bootstrap with 2000 replications for inference, following Goncalves and Kilian (2004) 5

I present results for the historical decompositions, the impulse response functions, and the estimated trends in the following. I complement my statistical analysis with narrative evidence on events in the respective markets. This provides a plausibility check to the identified shocks. Please find the narrative evidence for each of the four markets in the Online-Appendix.

\footnotetext{
${ }^{5}$ See the Online-Appendix at https://sites.google.com/site/mstuermer1/research-1 for the estimated coefficients.
} 


\subsection{Historical Decomposition}

The historical decomposition of each mineral commodity price quantifies the contribution of the three structural shocks to the deviation of the respective price from its base projection. Each of the three sub-panels shows how prices would have developed were there only the respective shock. Since the vertical scales across the three sub-panels are identical, the figures illustrate the relative importance of a given shock. The results show that the large fluctuations in the prices of copper, lead, tin, and zinc are mainly driven by "world outputdriven demand shocks" and "other demand shocks". These two types of shocks basically cause the long- and medium-run fluctuations. "Commodity supply shocks" play some role in driving the prices of copper and tin. They are a source for short-run fluctuations in these two markets.

The historical decompositions in Figures 2 to 5 illustrate that the accumulated contributions of "world output-driven demand shocks" are the main driver for the long-run fluctuations of all four prices. They follow the same pattern across the four commodities. This is as expected, as shocks to world output are common shocks and affect the price at the same time. However, this type of shock seems to affect copper and tin prices in a slightly more pronounced way than the ones for zinc and lead.

\section{Insert Figures 2 to 5 about here.}

The evolution of these accumulated shocks are in line with narrative evidence from 
economic history. In the late 1840 s the prices of the four commodities were low owing to the British railway crisis from 1847 to $1848^{6}$, which caused negative "world outputdriven demand shocks". In the 1850s prices underwent a major upswing, driven mainly by positive "world output-driven demand shocks" due to the world economic boom at that time. Prices experienced a long downturn during the 1860s, reaching a trough around 1870. This was due to negative "world output-driven demand shocks" triggered by the Panic of 1857, the U.S.-American Civil War from 1861 to 1865, and the Overend-Gurney Crisis in 1866 and their respective economic aftermaths.

In the interwar periods, the Great Depression caused a major negative "world outputdriven demand shocks" that drove down all prices in 1929. From the end of the Second World War until the mid 1970s, time post-war reconstruction and the economic rise of Japan generated strong, positive "world output-driven demand shocks", which mainly determined price fluctuations. This evidence of strong "world output-driven demand shocks" in the 1950 s to the 1970s suggests that the oil price spike in 1973 might have partly been driven by the lifting of price controls in 1973, which caused the price to catch up to the high levels of other commodity prices due to the accumulated effect of demand shocks. The recession in 1974 caused strong negative "world output-driven demand shocks", which led to a serious decline in prices from about 1975, In the following three decades prices fell mainly because of the negative "world output-driven demand shocks" caused by the recession in 1981, the economic impact of the breakup of the U.S.S.R., and the Asian crisis.

\footnotetext{
${ }^{6}$ See Kindleberger and Aliber $(2011)$ for an account of fluctuations in world output before the First World War
} 
The sharp rise in prices from around 2003 to 2007 was basically driven by the cumulative effects of large "world output-driven demand shocks" due to China. Since the onset of the Great Recession in 2008 "world output-driven demand shocks" have had a negative effect on prices.

"Commodity supply shocks" only play a modest role in determining short-term fluctuations in copper and tin prices. Narrative evidence suggests that copper and tin markets are characterized by a long history of oligopolistic structures and continued attempts to manipulate prices by output restrictions and stock-holdings. Copper production has also always been strongly concentrated, with the main producers in Chile and the U.S. (Schmitz, 1979). Chandler (1990) points out that the largest U.S. copper producers in 1917 were still under the top five in 1930 and in 1948. Recurrently appearing cartels were able to influence the price by both output restrictions and by attempts to corner the markets through inventories. The tin market is also characterized by a strong geographic narrowness of supplies in the Earth's crust (Gibson-Jarvie, 1983). During history production shifted from England, to the Straits and Australia, and then to the South-East Indies Gibson-Jarvie, 1983). Today, the main mine producers are China, Indonesia, and Peru. Tin is one the mineral commodities, whose supply depends strongest on less developed countries (Thoburn, 1994). Governments have attempted to control the market since after the First World War.

In contrast, "commodity supply shocks" do not play a role in driving the prices of lead and zinc. My historical account reveals that the two markets do not have a strong 
oligopolistic structure so that supply is quite elastic. This is due to the fact that lead and zinc resources are relatively widespread and production takes mainly place in the industrialized countries (BGR, 2007). As a consequence, the formation of cartels to restrict output has not been successful in the history of these markets.

The historical decompositions show that the accumulated contribution of "other demand shocks" play an important role in driving medium- to short-run fluctuations in all considered markets. The historical accounts provide evidence that the markets have been basically driven by changes in inventories by cartels, the U.S. government, and recently by increases in demand for inventories at metal exchanges. In the case of lead "other demand shocks" also encompass negative shocks to the use of lead due to environmental regulation in the 1970s and 1980s. Another unusual episode is in the tin market after the Second World War. The accumulated "other demand shocks" nicely show the build-up and collapse of the International Tin Agreement, which influenced the price strongly over several decades.

\subsection{Impulse Responses}

The impulse response functions in Figures 6 to 9 plot the respective responses of the percentage change in world GDP, the percentage change in world mineral commodity production, and the log in the respective real commodity price to a one-standard deviation of the three respective structural shocks. I use accumulated impulse response functions for the shocks to world mineral commodity production and world GDP to trace the long-term 
effects on the levels of these variables.

\section{Insert Figures 6 to 9 about here.}

The impulse response functions show that "world output-driven demand shocks" and "other demand shock" affect the price up to five-teen years. The effects of "commodity supply shocks" on price are far less pronounced and loose their importance after about five years in the cases of copper and tin, or are completely insignificant in the cases of zinc and lead.

A positive "world output-driven demand shock" triggers a major increase in the real prices of copper and tin for a maximum of about one year after the shock. This shock continues to persist significantly over a period of five-teen and ten years respectively. It also exhibits major increases in the prices for lead and zinc, which persist significantly for seven and five years respectively. At the same time, this shock causes a positive and significant increase in production that lasts for about three years in the case of copper and about four years in the cases of tin and zinc. The production of lead increases persistently. As expected, the shock has a positive and persistent effect on world GDP.

A positive shock to the supply of the respective commodities reduces the real price of copper significantly for more than ten years and the one for tin significantly for more than fifteen years. In contrast, positive "commodity supply shocks" lead to only insignificant decreases in the prices of lead and zinc. An explanation for these variations are different market structures between the rather concentrated tin and copper markets and the rather 
competitive markets of lead and zinc (Rudolf Wolff \& Co Lt., 1987; Schmitz, 1979; BGR, 2007). As a consequence, shocks to supply, in the form of coordinated production decreases by a cartel, for example, have an impact on the price of copper, but not on the price of lead. A positive shock to the supply of tin and copper affects GDP positively and significantly for three to seven years respectively and then approaches zero, in accordance with our identifying assumptions. It does not have any significant effect on GDP in the cases of the lead and zinc markets. As expected, this shock has a positive and persistent effect on production of the respective commodity.

A positive "other demand shock" has an immediate and statistically significant impact on all four commodities, which levels off in a period of about fifteen years. This shows how persistent the effect of stockholdings on price in these markets are. This type of shock exhibits some significant negative effect on GDP and some positive effect on production in the first couple of years in the copper and tin markets. There is no long-term impact due to my identifying assumptions. It does not have any significant effect on world GDP and production for lead and zinc.

\subsection{Long-Term Trends}

The estimated coefficients of the linear trends in the four estimated VAR models show that prices - with the exception of copper - have basically been trend-less from 1840 to 2010. The negative linear trend is statistically significant at the five percent level in the case of the copper price and only statistically significant at the ten percent level in the 
cases of the lead and zinc prices. The estimated coefficients for the linear trends in the tin price is zero.

\section{Insert table 1 about here.}

\section{$5 \quad$ Sensitivity Analysis}

I have employed several robustness checks, including an alternative identification scheme, and different time periods and alternative price data to test, whether my main results hold. To ease comparison, I present the results of forecast error variance decompositions for each of the respective specifications in the Online-Appendix.

I first compare my baseline results to those of an alternative identification, for which I use an identification scheme based on short-run restrictions as proposed by Kilian (2009). I postulate a vertical short-run supply curve and no effect of price changes driven by "other demand shocks" on world GDP within the first year. I describe the identification in detail in the Online-Appendix. Even if the identifying restrictions are questionable when relying on annual data, the empirical results are relatively similar. As Table 19 in the OnlineAppendix shows, my results stand up with respect to the overall strong impact of demand shocks on the prices of copper, lead, tin, and zinc. However, the effect of commodity supply shocks on the prices of tin and copper do not show up due to the restrictions that I apply regarding the instantaneous impact of "world output-driven demand shocks" and "other demand shocks" on commodity production. 
My results are robust regarding different lag lengths. Table 20 in the Online-Appendix shows that the overall results are relatively similar for using lag lengths of three and six, respectively, compared to the bench-line case, where I chose the lag lengths according the Akaike Information Criterion.

The empirical results confirm robustness regarding alternative price data. Table 21 in the Online-Appendix illustrates that using the producer price index instead of the consumer price index for disinflation does not lead to major changes in the relative contribution of the shocks to the fluctuations of prices. Employing New York prices instead of London based prices (see Table 22 in the Online-Appendix) increases the contribution of commodity supply shocks and reduces the contribution of demand shocks due to unexpected changes in world output significantly in the cases of tin and copper prices. In the cases of the lead and zinc market, "other demand shocks" strongly dominate other shocks. These results illustrate how strong government intervention and stockpiling, the imposing of restrictions on trade policies, and producer prices have dominated non-ferrous metals markets in the U.S. most of the time, whereas the market in London was basically the market-based price setter on a global scale (see also Slade, 1989).

Finally, I check the results for robustness with respect to different sub-periods. Starting the observation period in 1900 or 1925 does not change the general results in the cases of copper, lead, tin, and zinc (see Table 23 in the Online-Appendix). 


\section{Conclusion}

This paper has examined the dynamic effects of demand and commodity supply shocks on the real prices of copper, lead, tin, and zinc over the time period from 1840 to 2010 . Using a historical decomposition based on a structural VAR model with long-term restrictions, my results show that these prices are mainly driven by persistent "world output-driven demand shocks" and "other demand shocks", namely shocks to inventory demand. Commodity supply shocks play a role only in the cases of tin and copper, possibly due to the oligopolistic structure of these markets.

My results contribute to the literature by providing long-term empirical evidence from a new data set on mineral commodity prices. Two major limitations to my analysis may guide further research. First, my model does not include asymmetric responses of prices to positive or negative shocks. This may be particularly important for the effect of positive and negative commodity supply shocks on prices and vice versa. For example, Radetzki (2008) describes an experience which is common in the extractive sector, namely that firms keep their utilization rates high even after negative price and demand shocks hit the market. Second, "other demand shocks" capture all shocks that are orthogonal to "commodity supply shocks" and "world output-driven demand shocks". Disentangling these shocks by explicitly controlling for changes in inventories or the resource intensity of the economy would shed further light on the sources of these shocks. 


\section{References}

Alquist, R. and Kilian, L. (2010). What do we learn from the price of crude oil futures? Journal of Applied Econometrics, 25(4):539-573.

Arrow, K. and Chang, S. (1982). Optimal pricing, use, and exploration of uncertain natural resource stocks. Journal of Environmental Economics and Management, 9(1):1-10.

Backman, J. and Fishman, L. (1941). British war-time control of copper, lead, and zinc. The Quarterly Journal of Economics, 55(2):210-238.

Barsky, R. and Kilian, L. (2002). Do we really know that oil caused the great stagflation? A monetary alternative. In NBER Macroeconomics Annual 2001, Volume 16, pages 137-198. National Bureau of Economic Research, Inc, MIT Press, Cambridge, M. A.

Barsky, R. and Kilian, L. (2004). Oil and the macroeconomy since the 1970s. Journal of Economic Perspectives, 18(4):115-134.

BGR $=$ Federal Institute for Geosciences and Natural Resources (2007). Rohstoffwirtschaftliche Steckbriefe für Metall- und Nichtmetallrohstoffe. Federal Institute for Geosciences and Natural Resources (Bundesanstalt fr̈ Geowissenschaften und Rohstoffe), Hanover.

Blanchard, O. and Quah, D. (1989). The dynamic effects of aggregate demand and supply disturbances. The American Economic Review, 79(4):655-673.

Bodenstein, M., Guerrieri, L., and Kilian, L. (2012). Monetary policy responses to oil price fluctuations. IMF Economic Review, 60(4):470-504.

Cafiero, C., Bobenrieth H., E., Bobenrieth H., J., and Wright, B. (2011). The empirical relevance of the competitive storage model. Journal of Econometrics, 162(1):44-54.

Cairns, R. and Lasserre, P. (1986). Sectoral supply of minerals of varying quality. The Scandinavian Journal of Economics, 88(4):605-626.

Carter, C., Rausser, G., and Smith, A. (2011). Commodity booms and busts. Annual Review of Resource Economics, 3:87-118.

Chandler, A. D. (1990). Scale and scope. The Belknap Press of Harvard University Press, Cambridge, M.A., and London.

Cleveland, C. and Szostak, R. (2008). Material intensity of use. In Cleveland, C., editor, The encyclopedia of Earth. Environmental Information Coalition, National Council for Science and the Environment, Washington, D.C. http://www.eoearth.org/article/Material_intensity_of_use (accessed on November 9, 2010). 
Cuddington, J. and Jerrett, D. (2008). Super cycles in real metals prices? IMF Staff Papers, 55(4):541-565.

Cynthia-Lin, C. and Wagner, G. (2007). Steady-state growth in a Hotelling model of resource extraction. Journal of Environmental Economics and Management, 54(1):6883.

Deaton, A. and Laroque, G. (1996). Competitive storage and commodity price dynamics. The Journal of Political Economy, 104(5):896-923.

Dvir, E. and Rogoff, K. (2010). The three epochs of oil. mimeo.

Erten, B. and Ocampo, J. (2012). Super-cycles of commodity prices since the midnineteenth century. United Nations Department of Economic and Social Affairs Working Paper, 2012(110).

Findlay, R. and O'Rourke, K. (2007). Power and plenty. Trade, war, and the world economy in the second millennium. Princeton University Press, Princeton.

Fourgeaud, C., Lenclud, B., and Michel, P. (1982). Technological renewal of natural resource stocks. Journal of Economic Dynamics and Control, 4(1):1-36.

Frankel, J. and Hardouvelis, G. (1985). Commodity prices, money surprises and fed credibility. Journal of Money, Credit and Banking, 17(4):425-438.

Frankel, J. and Rose, A. (2010). Determinants of agricultural and mineral commodity prices. In Fry, R., Jones, C., and Kent, C., editors, Inflation in an era of relative price shocks, RBA Annual Conference Volume, pages 9-51. Reserve Bank of Australia, Sydney.

Gibson-Jarvie, R. (1983). The London Metal Exchange: a commodity market. WoodheadFaulkner Ltd., Herts.

Goncalves, S. and Kilian, L. (2004). Bootstrapping autoregressions with conditional heteroskedasticity of unknown form. Journal of Econometrics, 123(1):89-120.

Gustafson, R. (1958a). Carryover levels for grains: a method for determining amounts that are optimal under specified conditions, volume 1178. U.S. Dept. of Agriculture, Washington, D.C.

Gustafson, R. (1958b). Implications of recent research on optimal storage rules. Journal of Farm Economics, 40(2):290-300.

Hamilton, J. (2008). The new Palgrave dictionary of economics, chapter Oil and the Macroeconomy. MacMillan, London. 
Hanes, C. (1998). Business cycles since 1820. New international perspectives from historical evidence. Consistent wholesale price series for the United States, 1860-1990. Edward Elgar, Cheltenham.

Hotelling, H. (1931). The economics of exhaustible resources. Journal of Political Economy, 39(2):137-175.

IMF = International Monetary Fund (2012). World Economic Outlook. Growth resuming, dangers remain. International Monetary Fund, Washington D.C.

Jacks, D., O'Rourke, K., and Williamson, J. (2011). Commodity price volatility and world market integration since 1700. The Review of Economics and Statistics, 93(3):800-813.

Jacks, D. S. (2013). From boom to bust:a typology of real commodity prices in the long run. NBER Working Papers 18874, National Bureau of Economic Research, Inc.

Kilian, L. (2008a). The economic effects of energy price shocks. Journal of Economic Literature, 46(4):871-909.

Kilian, L. (2008b). Exogenous oil supply shocks: how big are they and how much do they matter for the US economy? The Review of Economics and Statistics, 90(2):216-240.

Kilian, L. (2009). Not all oil price shocks are alike: disentangling demand and supply shocks in the crude oil market. American Economic Review, 99(3):1053-69.

Kilian, L. and Lee, T. (2013). Quantifying the speculative component in the real price of oil: The role of global oil inventories. Journal of International Money and Finance.

Kilian, L. and Murphy, D. P. (2013). The role of inventories and speculative trading in the global market for crude oil. Journal of Applied Econometrics.

Kindleberger, C. and Aliber, R. (2011). Manias, panics and crashes: a history of financial crises. Palgrave Macmillan, Basingstoke.

Klovland, J. (2005). Commodity market integration 1850-1913: evidence from Britain and Germany. European Review of Economic History, 9(02):163-197.

Krautkraemer, J. (1998). Nonrenewable resource scarcity. Journal of Economic Literature, 36(4):2065-2107.

Labys, W. (2008). Modeling and Forecasting of Primary Commodity Prices. Ashgate, Burlington.

Lee, J., List, J., and Strazicich, M. (2006). Non-renewable resource prices: deterministic or stochastic trends? Journal of Environmental Economics and Management, 51(3):354370 . 
Lütkepohl, H. and Krätzig, M. (2004). Applied time series econometrics. Cambridge University Press, Cambridge.

Maddison, A. (2010). Historical statistics of the world economy: 1-2008 AD. http://www.ggdc.net/maddison/ (accessed on June 13, 2011).

Mitchell, B. (1988). British historical statistics. Cambridge University Press, Cambridge.

Mitraille, S. and Thille, H. (2009). Monopoly behaviour with speculative storage. Journal of Economic Dynamics and Control, 33(7):1451-1468.

O’Rourke, K. and Williamson, J. (1994). Late nineteenth-century Anglo-American factorprice convergence: were Heckscher and Ohlin right? The Journal of Economic History, 54(4):892-916.

Pindyck, R. (1999). The long-run evolution of energy prices. The Energy Journal, 20(2):128.

Pindyck, R. and Rotemberg, J. (1990). The excess co-movement of commodity prices. The Economic Journal, 100(403):1173-1189.

Pindyck, R. S. (1980). Uncertainty and exhaustible resource markets. The Journal of Political Economy, pages 1203-1225.

Radetzki, M. (2008). A handbook of primary commodities in the global economy. Cambridge Univ. Press, Cambridge, U.K.

Rasmussen, T. and Roitman, A. (2011). Oil shocks in a global perspective: are they really that bad? IMF Working Papers 11/194, International Monetary Fund, Washington D.C.

Rudolf Wolff \& Co Lt., editor (1987). Wolff's guide to the London Metal Exchange. Metal Bulletin Books Ltd., London.

Schmitz, C. (1979). World non-ferrous metal production and prices 1700-1976. Frank Cass, London.

Slade, M. (1982). Trends in natural-resource commodity prices: an analysis of the time domain. Journal of Environmental Economics and Management, 9(2):122-137.

Slade, M. (1989). The two pricing systems for non-ferrous metals. Resources Policy, $15(3): 209-220$.

Slade, M. (1991). Market structure, marketing method, and price instability. The Quarterly Journal of Economics, 106(4):1309-1340.

Slade, M. and Thille, H. (2006). Commodity spot prices: an exploratory assessment of market structure and forward-trading effects. Economica, 73(290):229-256. 
Stuermer, M. and von Hagen, J. (2012). The impact of the bric countries on mineral commodity markets. DERA Rohstoffinformationen 11, German Federal Mineral Resources Agency, Berlin.

Svedberg, P. and Tilton, J. (2006). The real, real price of nonrenewable resources: copper 1870-2000. World Development, 34(3):501-519.

The Conference Board (2012). The Conference Board total economy database. Regional aggregates. January 2012. The Conference Board, New York.

Thoburn, J. (1994). Tin in the world economy. Edinburgh University Press, Edinburgh.

U.S. Bureau of Labor Statistics (2011). Producer price index: all commodities. http://www.bls.gov/ppi/ (accessed July 29, 2011).

Wellmer, F. (1992). The concept of lead time. Minerals Industry International, 1005.

World Bank (2012). World bank database. http://data.worldbank.org/ (accessed January $23,2012)$.

World Trade Organization (2010). World trade report 2010. Trade in natural resources. World Trade Organization, Geneva.

Wright, B. and Williams, J. (1982). The economic role of commodity storage. The Economic Journal, 92(367):596-614. 


\section{A Appendix: Figures and Tables}
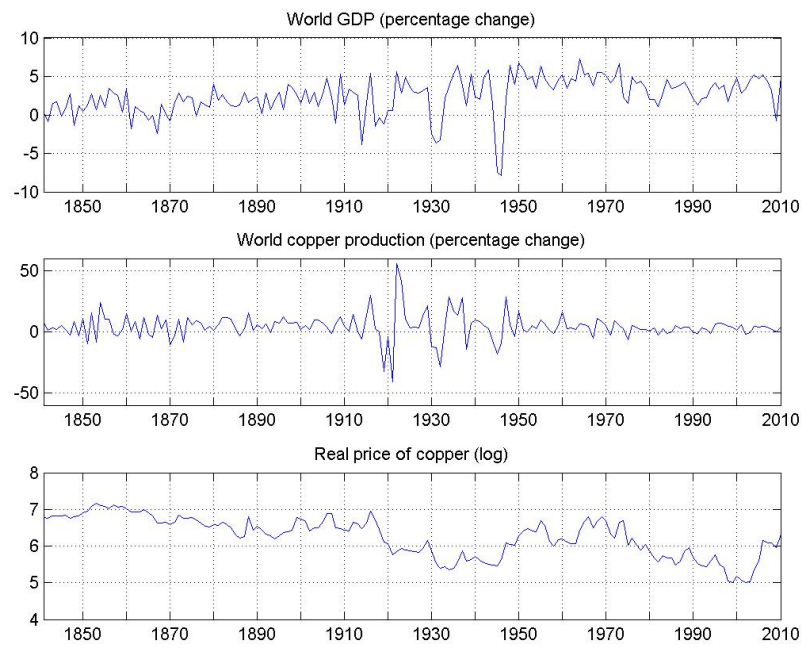

Notes: For other mineral commodities see the Online-Appendix.

Figure 1: Historical evolution of world GDP, world copper production, and the real price of copper from 1841 to 2010. 

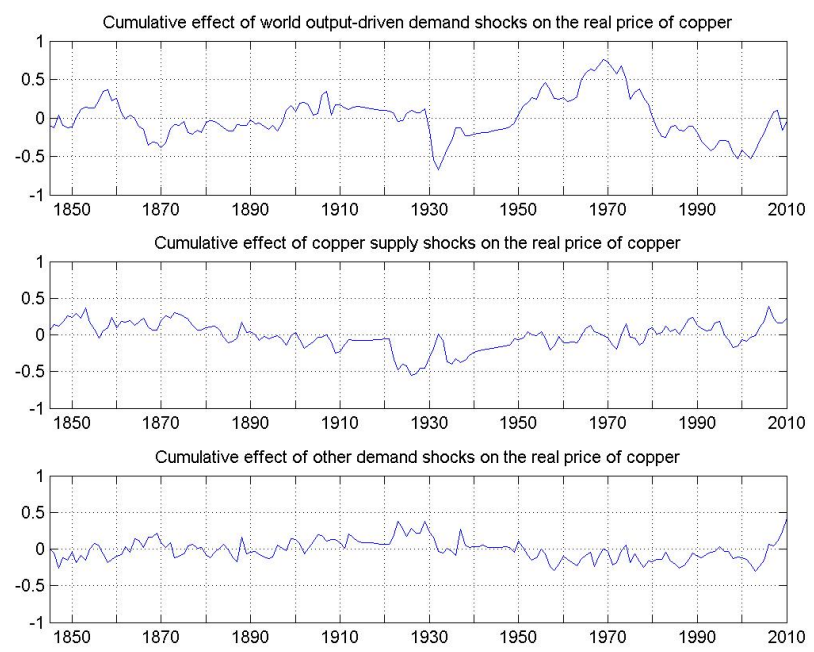

Notes: The historical decomposition quantifies the relative contribution of the three specific shocks to the deviation of the actual copper price data from its base projection.

Figure 2: Historical decomposition of the real price of copper.
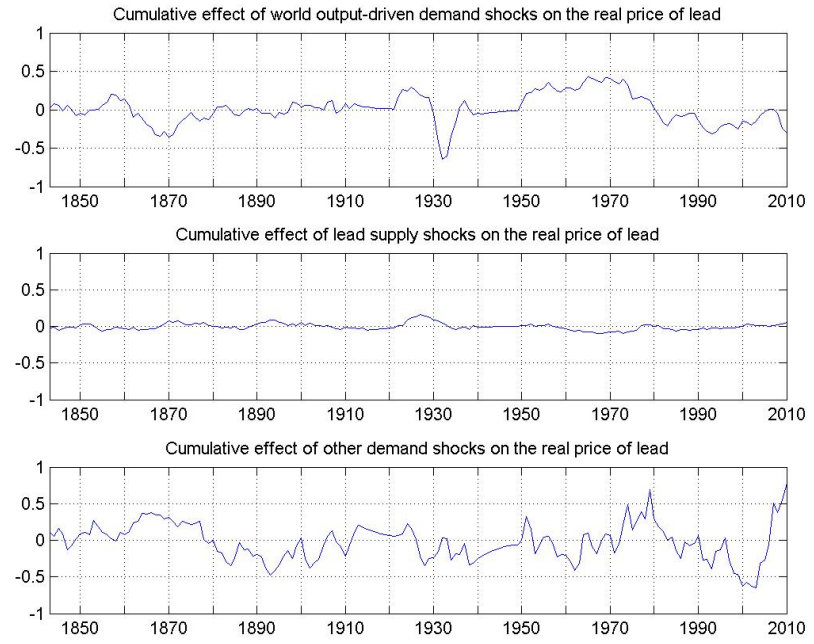

Figure 3: Historical decomposition of the real price of lead. 

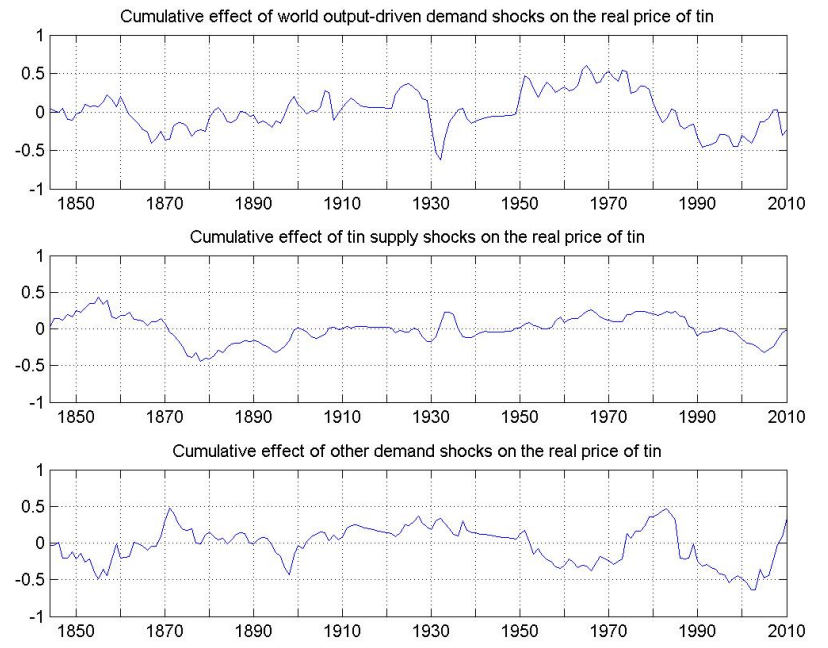

Figure 4: Historical decomposition of the real price of tin.
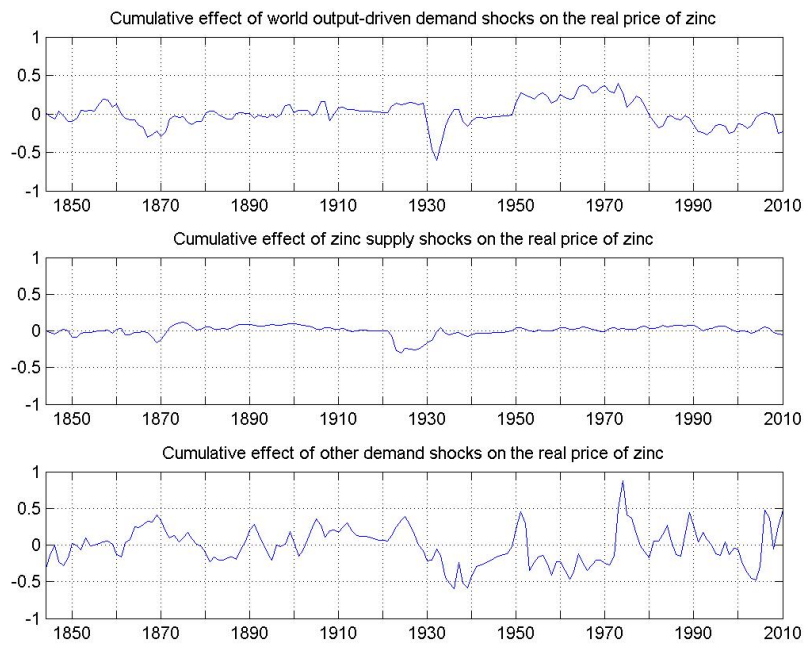

Figure 5: Historical decomposition of the real price of zinc. 

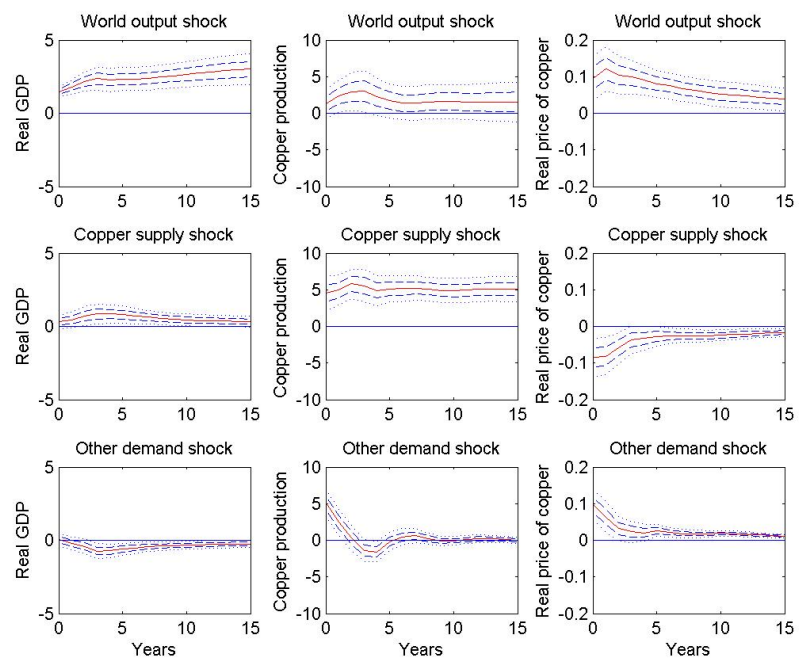

Notes: Point estimates with one- and two-standard error bands based on Model (1). I use accumulated impulse response functions for the shocks to world mineral commodity production and world GDP to trace the effects on the level of these variables. For the other mineral commodities see the Appendix.

Figure 6: Impulses to one-standard-deviation structural shocks for copper.
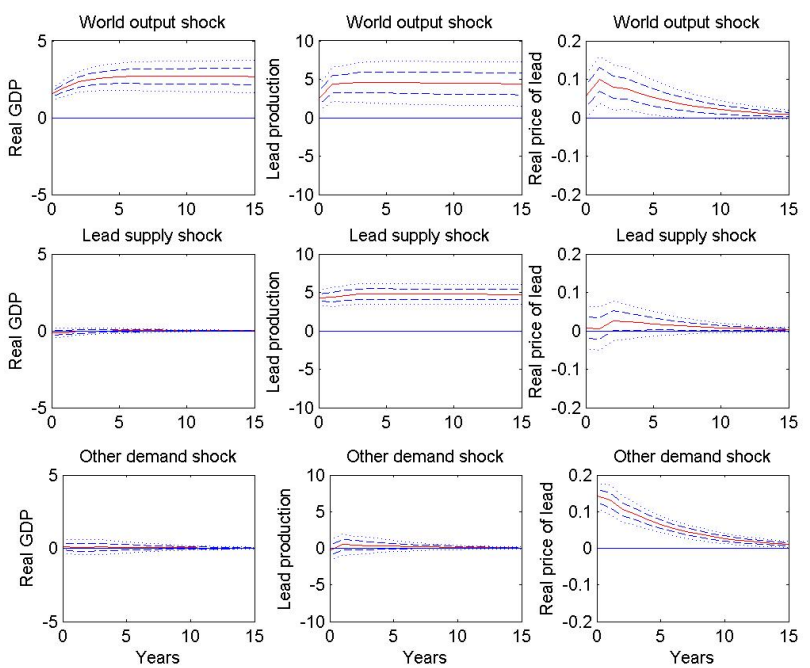

Notes: Point estimates with one- and two-standard error band based on Model (1). I use accumulated impulse response functions for the shocks on world mineral commodity production and world GDP to trace out the effects on the levels of these variables.

Figure 7: Impulses to one-standard-deviation structural shocks for lead. 

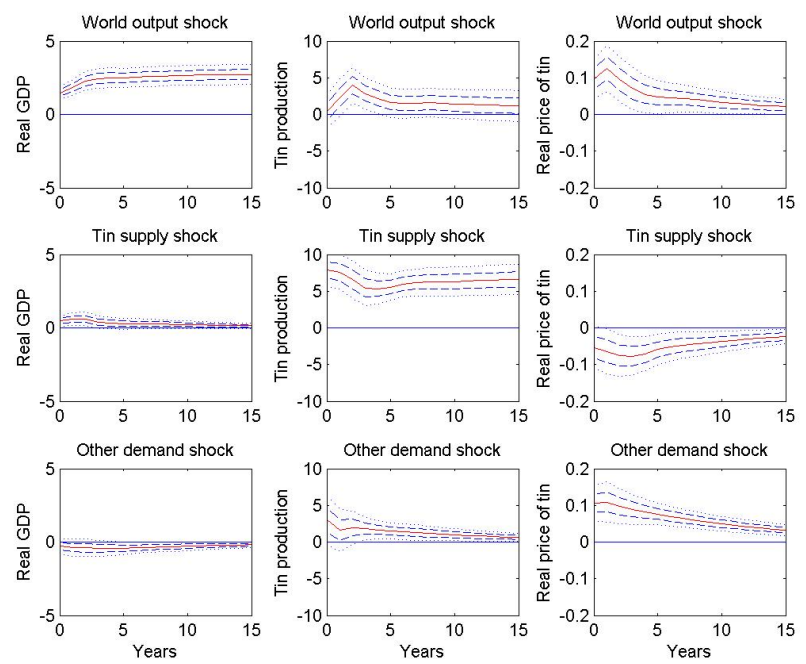

Notes: Point estimates with one- and two-standard error bands based on Model (1). I use accumulated impulse response functions for the shocks on world mineral commodity production and world GDP to trace out the effects on the levels of these variables.

Figure 8: Impulses to one-standard-deviation structural shocks for tin.
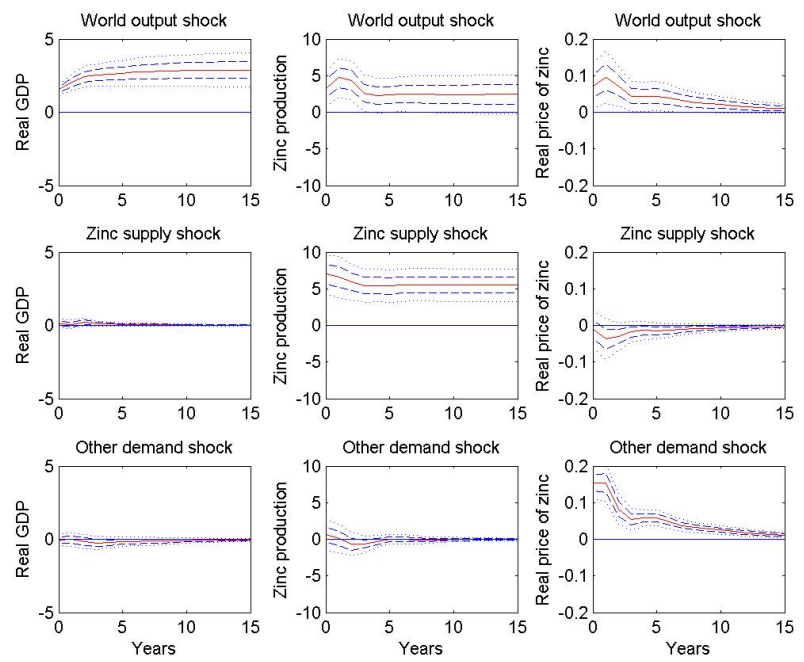

Notes: Point estimates with one- and two-standard error bands based on Model (1). I use accumulated impulse response functions for the shocks on world mineral commodity production and world GDP to trace out the effects on the levels of these variables.

Figure 9: Impulses to one-standard-deviation structural shocks for zinc. 


\begin{tabular}{lrrr}
\hline & Est. coefficient & t-stat. & t-prob. \\
\hline Copper & -0.002 & -2.811 & 0.006 \\
Lead & -0.001 & -1.871 & 0.063 \\
Tin & 0.000 & 0.315 & 0.753 \\
Zinc & -0.001 & -1.777 & 0.077 \\
\hline
\end{tabular}

Table 1: Estimated coefficients of the linear trends. 